\title{
Tıbbi Olarak Kullanılan Bazı Yabancı Ot Tohumlarının Çimlenmeleri Üzerine Farklı Uygulamaların Etkileri
}

\author{
Ayșe Özlem TURSUN ${ }^{1}$, K. Sinan DAYISOYLU ${ }^{2}$, Nihat TURSUN ${ }^{3 *}$ \\ ${ }^{1}$ İnönü Üniversitesi, Battalgazi Meslek Yüksek Okulu, Battalgazi, Malatya \\ ${ }^{2}$ KSÜ Mühendislik ve Mimarlık Fak., Gıda Müh. Böl. Kahramanmaraş \\ ${ }^{3}$ İnönü Üniversitesi Ziraat Fakültesi, Bitki Koruma Bölümü, Battalgazi, Malatya
}

Geliş (Received): 10.11.2015

Kabul (Accepted): 23.11.2015

ÖZET: Çalışma; Senecio vulgaris L., Taraxacum officinale L. ve Tragopogon pratensis L. tohumlarının çimlenmesi üzerine sıcaklık, bekleme süresi, $\mathrm{pH}, 1$ şık ve tuzun etkilerini belirlemek amacıyla yapılmıştır. Çalışma sonucunda $S$. vulgaris $15, T$. officinale 20 ve T. pratensis ise $10^{\circ} \mathrm{C}^{\prime}$ de, bekleme süresinde her üç tohumda 6 ay, $\mathrm{pH}$ açısından $\mathrm{pH} 7, S$. vulgaris ve T. officinale 16 saat aydınlık/ 8 saat karanlı, T. pratensis ise 24 saat karanlık, tuz istekleri bakımından ise kontrolde en fazla çimlenme oranına sahip oldukları tespit edilmiştir.

Anahtar Kelimeler: Tıbbi yabancı otlar, sıcaklık, 1şık, pH, tuz

\section{Effects of Different Practices on Seed Germination of Some Weeds Which is used as Medical}

ABSTRACT: Study was conducted to determine the effect of temperature, scarification, the pH, light duration and salt concentration on Senecio vulgaris L., Taraxacum officinale L. and Tragopogo pratensis L. seeds. In the study results were determined the highest germination rate in $15^{\circ} \mathrm{C}$ for $S$. vulgaris, $20^{\circ} \mathrm{C}$ for T. officinale and $10^{\circ} \mathrm{C}$ for $T$. pratensis, at each of the three seeds in 6 months in waiting period, 7 for $\mathrm{pH}, 16$ hours light $/ 8$ hours dark for $S$. vulgaris and $T$. officinale, 24 hours darkness for $T$. pratensis and in control for salt concentration in each of the three seeds. In case of the culture of these three weeds which used medical should be taken into the consideration to these conditions.

Key Words: Medicinal weeds, temperature, light duration, pH, salt concentration

\section{GİRIŞ}

Tibbi ve aromatik bitkilerden faydalanma ilk insanla başlar ve günümüze kadar devam eder. $\mathrm{Bu}$ bitkiler zaman içerisinde az veya çok önemli konuma gelmişlerdir. Ancak hiçbir zaman önemlerini tamamen yitirmemişlerdir. (Başer, 1998). Türkiye, tıbbi ve aromatik bitkiler bakımından dünyanın en zengin ülkelerinden birisidir. Türkiye florasında 12,000'in üzerinde bitki kayıtlıdır ve bunların \% 30'u endemiktir (Baydar, 2013, Davis, 1965-1985; Davis ve ark., 1988; Güner ve ark., 2000). Endemikler başta olmak üzere Türkiye'de doğal olarak yetişen yüzlerce bitki türünün tıbbi ve aromatik değeri çok yüksektir. Türkiye'de yaklaşık 500 kadar bitki türünden halk hekimliği veya geleneksel tı uygulamaları kapsamında faydalanılmaktadır (Baydar, 2013). Asteraceae familyasından Avrupa'da kültürü yapılan, ülkemizde doğal olarak çok yaygın olarak bulunan S. vulgaris uterotonik, diüretik ve kan kesici olarak (Kalafatçı ve Kalafatçı, 2010) kökleri hariç tamamı tentür veya doğal ilaç yapımında kullanılır, fakat nadiren de olsa çayı içilebilen bir tıbbi bitkidir. Yine Asteraceae familyasından çok yıllık bir bitki olan $T$. officinale yüksek oranda kan temizleyici özelliğe sahip olması sebebiyle kan hastalıklarına karşı, egzama gibi cilt hastalıkları ve romatizmal ağrılara karşı halk hekimliğinde kullanılan bir bitkidir (Kalafatçı ve Kalafatçı, 2010). İki yıllık bir bitki olan yine Asteraceae familyasından $T$. pratensis ise beslenme amaçlı kullanılmaktadır (Özer ve ark., 2001). Ayrica T. pratensis' in yaprakları B2, B3, B6 ve $\mathrm{C}$ vitaminleri, $\beta$ karoten miktarları ve total antioksidan kapasitesi bakımından oldukça zengindir (Çöteli ve Karataş, 2015). Tarımda tohum kullanımı vazgeçilmez bir unsur olup (Yentur, 1995) yeni bir bitki oluşturabilecek potansiyeli sahiptir (Baydar, 2013). Tohum çimlenmesinin başlaması ve devam etmesi farklı bitki tür tohumlarının niteliği ve özel isteğine göre değişmekle birlikte önemli çevre faktörleri (su, sıcaklık, oksijen ve 1şık) istenen seviyede ortamda bulunmasına bağlıdır (Karakurt ve ark., 2010). Bitki yaşamının en önemli fazlarından biri olan çimlenme tuzluluk, sıcaklık, 1şık, besidoku, nem patojenlerden kurtulma, tohum kalitesi ve dormansiden kurtulma gibi koşullara bağlıdır (Otsamo ve ark., 1996). Çimlenme süresini düzenleyen en önemli faktörlerden birisi sıcaklıktır. Düşük sıcaklıkta çimlenme oranı düşük olup dormansi ile doğrudan ilgilidir. Düşük ve yüksek toprak sıcaklığı, tohumun küçük olması, tohumların kalın kabuğa sahip olması, toprak kaymak tabakası, ağır bünyeli toprak, toprak tuzluluğu, kuraklık gibi koşullar tohumlarda strese sebep olarak geç ve düzensiz çimlenmeye veya çimlenmenin hiç oluşmamasına neden olmaktadır (Heydecker ve Coolbear, 1977). Bitki büyüme ve gelişmesini olumsuz yönde etkileyen tuzluluk (Çavuşoğlu ve ark., 2007), çimlenmeyi etkileyen en önemli çevre faktörlerindendir (Demir ve ark., 2003). Ayrıca, tuzluluğun; tohum çimlenmesini engellediği 
(Kabar ve Baltepe 1987, Gulzar ve Khan 2002), kök ve gövde uzamasını baskıladığı (Dash ve Panda 2001), çimlenme oranını olumsuz etkilediğini (Almansori ve ark., 2001) bir çok araştırmacı tarafından saptanmıştır. Yüksek tuz konsantrasyonunda çimlenme döneminde görülen bu olumsuzluğun esas nedeni tohum içerisine su alımının engellenmesidir (Mansour, 1994).

Araştırıcılar tohumların doğal habitatlarında çimlenmelerini düzenleyen birçok mekanizmanın olduğunu, çimlenme için önemli isteklerden birinin de ortamın $\mathrm{pH}$ değeri olduğunu bildirmişlerdir (Schütz, 1997, Taiz ve Zeiger 1998). Topraklarda pH değerinin yükselmesi ile alınabilir mikro element içerikleri azalmakta, bu da birçok türde sıcaklık, 1şık, toprak tuzluluğu, nem gibi diğer çevresel faktörlerle birlikte gerek tohum çimlenmesi (Baskın ve Baskın 1988, Ghorbani ve ark., 1999) gerekse bitki gelişiminde (Ağaoğlu ve ark. 1997, Güneş ve ark. 2000) olumsuz sonuçlara yol açmaktadır. Tıbbi ve aromatik bitkilere her geçen gün talebin artması bu bitkilerin doğandan toplanması yerine kültüre alınmasını gündeme getirerek (Hayta ve Arabac1, 2011) dünya tarımına "yeni kültür bitkileri" kazandıran en önemli alternatif kaynak olmasına neden olmuştur (Baydar, 2013). Ancak yetiştiricilik yönünden bu bitkilerle ilgili yeterli çalışmalar yapılmadığından birçok problemle karşılaşılmaktadır (Hayta ve Arabacı, 2011).

Bitkisel üretimde verim, bitkinin ilk çıkışından hasadına kadarki gelişme evrelerinde meydana gelen faktörlerin birleşmesinin bir sonucudur. Ayrıca kullanılan tohumluk, yetiştirme tekniği ve ekolojik koşullar da verimi etkilemektedir (Hayta ve Arabacı, 2011). Tıbbi ve aromatik bitkilerin yetiştiriciliğini yapmak isteyen üretici bitki tohumlarını kolay bulamamakta, bulduğu tohum sertifikalı tohumluk olmamakla birlikte, tohumluğu da yüksek fiyatta temin etmekte ve yetiştirdiğinde de birim alanda yeterli bitki sayısı sağlayamamaktadır (Hayta ve Arabac1, 2011).

Tohumların çimlenme oranlarını artırmak için günümüzde çimlenme öncesi bazı işlemlerin uygulanması yaygınlık kazanmıştır. Literatürlerde kültür bitkilerinin tohumları hakkında bir çok çalışma olmasına rağmen, tıbbi ve aromatik bitkilerinin tohumları ile ilgili yeterli çalışmaya rastlanılmamıştır. $\mathrm{Bu}$ çalışma ile diğer bitkilerde yaygın olarak kullanılan çimlendirmeyi artırıcı bazı uygulamaların yabancı ot olarak bilinen bazı tıbbi bitkilerinin $(S$. vulgaris, $\mathrm{T}$. officinale ve $T$. pratensis) tohumlarının çimlenmesi üzerindeki etkinliğinin belirlenmesi amaçlanmıştır.

\section{MATERYAL ve METOT}

Denemede kullanılan tohumlar Kahramanmaraş'tan toplanmış ve denemeler laboratuvar şartlarında inkübatörlerde tesadüf parselleri deneme desenine göre 5 tekerrürlü olarak kurulmuştur. Denemede kullanılan $S$. vulgaris ve $T$. officinale tohumlarından 25 ' er adet, $T$. pratensis tohumundan ise 10 adet 9 cm'lik Petri kaplarına iki kat petri kâğıdının üzerine yerleştirilmiştir. Filtre kağıtları başlangıçta 4 ml'lik distile su veya tuz çözeltisi ile 1slatılmış ve gerektikçe 1-3 ml su veya çözelti (uygulamaya göre) yeterli nemi korumak için eklenmiştir. Bütün petrilerde çimlenen tohumlar $(1 \mathrm{~mm}$ radikula/kökçük çıkışı olduğu zaman çimlenmiş sayılmış) 21 gün boyunca günlük olarak sayılmış ve petri kabından uzaklaştırılmıştır. Çalışmada, 21 gün sonunda petri kaplarından ayrılan çimlenmiş tohumların (radikula/kökçük görülünce) sayısı her bir uygulama için kaydedilerek çimlenme ile ilgili hesaplamalar (maksimum çimlenme oranı ve çimlenme üniformluk indeksi) aşağıdaki formüllere göre yapılmıştır (Akıncı ve Akınc1, 2010).

-Maksimum çimlenme oranı veya çimlenme oranı $\mathrm{G}-\max =(\mathrm{G} / \mathrm{T})^{*} 100$; G: çimlenen tohum sayısı, T: denemede kullanılan toplam tohum sayısı

\section{-Çimlenme üniformluk indeksi}

$\mathrm{G}_{50}$ : Çimlenen tohumların \% 50'sinin çimlenmesi için geçen süre arasındaki zaman

$\mathrm{G}_{90-10}$ : Çimlenen tohumların \% 90 ile \% 10'unun çimlenmesi için geçen süre arasındaki zaman (Jalink ve Van Der Schoor, 2000).

Çalışma 2 aşamada yapılmış, 1. aşamada bu üç tıbbi olarak kullanılan yabancı ot tohumlarının en uygun çimlenme sıcaklığı belirlenmiş ve böylece her bir tohum için en uygun çimlenme sıcaklığı saptanmıştır. Daha sonra 2. aşamada bu uygun sicaklıklarda tohumların, katlama, 1şık istekleri, $\mathrm{pH}$ ve tuz uygulamalarına olan tepkileri belirlenmiştir. Denemede araştırılan uygulamalar aşağıda verilmiştir.

\section{Sıcaklığın Etkisi}

Petri kaplarına yerleştirilen S. vulgaris, T. officinale ve T. pratensis tohumlarının $5,10,15,20,25,30,35{ }^{\circ} \mathrm{C}$ sabit sicaklıklarında en uygun çimlenme sicaklıklarını belirlemek için 21 gün laboratuvarda bulunan inkübatörlerde bekletilmiş ve her petri kabında çimlenen tohumlar kaydedilmiştir. Çimlenen tohumlar (1 mm radikula/kökçük çıkışı olduğu zaman çimlenmiş sayılmış) 21 gün boyunca günlük olarak sayım yapılmış ve çimlenen tohumlar petri kabından uzaklaştırılmıştır.

\section{Tohum Bekleme Süresi (Katlama)}

Toplanan tohumlar kontrol (taze olarak), 1, 2, 3, 4 ve 6 ay boyunca $+4{ }^{0} \mathrm{C}$ sicaklıkta bekletilmiş ve daha sonra her bir tohum için belirlenmiş olan uygun çimlenme sıcaklığında her bekletme süresinin sonunda petri kaplarında çimlenmeleri 21 gün boyunca günlük olarak takip edilmiş ve çimlenen tohumlar petri kabından uzaklaştırılmıştır.

\section{Işıı İstekleri}

Çimlenme üzerine 1şı̆̆ın etkilerini belirlemek amacıyla tohumlar 16 saat $1 s ̧ \mathrm{k}$ - 8 saat karanlık, 16 saat 
karanlık-8 saat 1 şık, 24 saat karanlık ve 24 saat 1 şıklı ortamlarda petri kaplarının içinde bekletilmiştir. Her bir tohum için belirlenmiş olan optimum sicaklıklarda uygulamalar yapılmış, çimlenen tohumlar (1 $\mathrm{mm}$ radikula/kökçük çıkışı olduğu zaman çimlenmiş sayılmış) 21 gün boyunca günlük olarak sayımmış ve çimlenen tohumlar petri kabından uzaklaştırılmıştır.

\section{pH İstekleri}

Denemede tohumlar 4, 5, 6, 7 ve $8 \mathrm{pH}$ tampon çözeltileri içerisine bırakılarak $\mathrm{pH}$ istekleri belirlenmiştir. Kontrol uygulaması için pH 7 olan distile su kullanılmıştır. Kullanılan bu suya 4, 5 ve 6 arasında tampon $\mathrm{pH}$ çözeltileri ayarlamak için $0.1 \mathrm{M}$ potasyum hidrojen ftalat (Clark ve Lubs 1916) kullanılarak istenilen $\mathrm{pH}$ derecesinde solüsyonlar hazırlanmıştır. Kontrol uygulamasında kullanılan $\mathrm{pH} 7$ olan solüsyonun $\mathrm{pH}$ 8'e çıkarmak için ise $0,2 \mathrm{M}$ borik asit çözeltisi ve $0,05 \mathrm{M}$ boraks çözeltisi tamponlu çözeltiler kullanılmıştır (Li ve ark., 2000). PH denemeleri de her bir tohum için belirlenmiş olan uygun sıcaklıklarda yapılmıştır. Solüsyonlar ihtiyaç duyuldukça her uygulama için 21 gün boyunca petrilere uygulanmış ve günlük olarak çimlenen tohumlar sayılmıştır.

Tuz İstekleri

Denemede kullanılan tohumların çimlenmesi üzerine tuzun etkisini belirlemek amaciyla sodyum klorit maddesi distile su ile $\% 0, \% 0,5, \% 1, \% 2$ ve $\% 4$ oranında çözelti olarak hazırlanmış ve günlük olarak çimlenen tohumlar sayılmıştır. Bu çalışmada her bir tohum için belirlenmiş olan uygun sicaklıklarda yapılmıştır. Elde edilen bu solüsyonlar ihtiyaç duyuldukça her bir uygulama için 21 gün boyunca petri kaplarına uygulanmış ve günlük olarak çimlenen tohumlar sayılmıştır.

\section{Verilerin Değerlendirilmesi}

Tohum çimlenmesi ile ilgili elde edilen verilerin analizi, MSTATC paket programı kullanılarak yapılmış $(\mathrm{P}<0.05)$ ve ortalamaların karşılaştırılmasında LSD testi kullanılmıștır.

\section{BULGULAR VE TARTIŞMA}

Çalışmada kullanılan yabancı otlardan $S$. vulgaris en fazla $15, T$. officinale 20 ve $T$. pratensis ise $10{ }^{\circ} \mathrm{C}$ sıcaklıkta çimlendiği saptanmıştır (Şekil 1). Deneme sonunda kanarya otu tohumlarının yaklaşık \% 85'i 15 ${ }^{0} \mathrm{C}$ sıcaklıkta çimlenirken, diğer sıcaklık derecelerinde çimlenme oranları hemen hemen \% 50'nin altında kalmıştır. T. officinale tohumlarında ise yaklaşık \% 90'ının $20{ }^{0} \mathrm{C}$ 'de çimlendiği saptanmış ve diğer sıcaklıklarda ise \% 60 ve daha aşağı oranlarda çimlendikleri saptanmıştır. T. pratensis'de ise tohumlar $10{ }^{0} \mathrm{C}$ 'de \% 100 oranında çimlenmiş ve diğer sıcaklık derecelerinde ise bu oranın çok altında kalmışlardır.

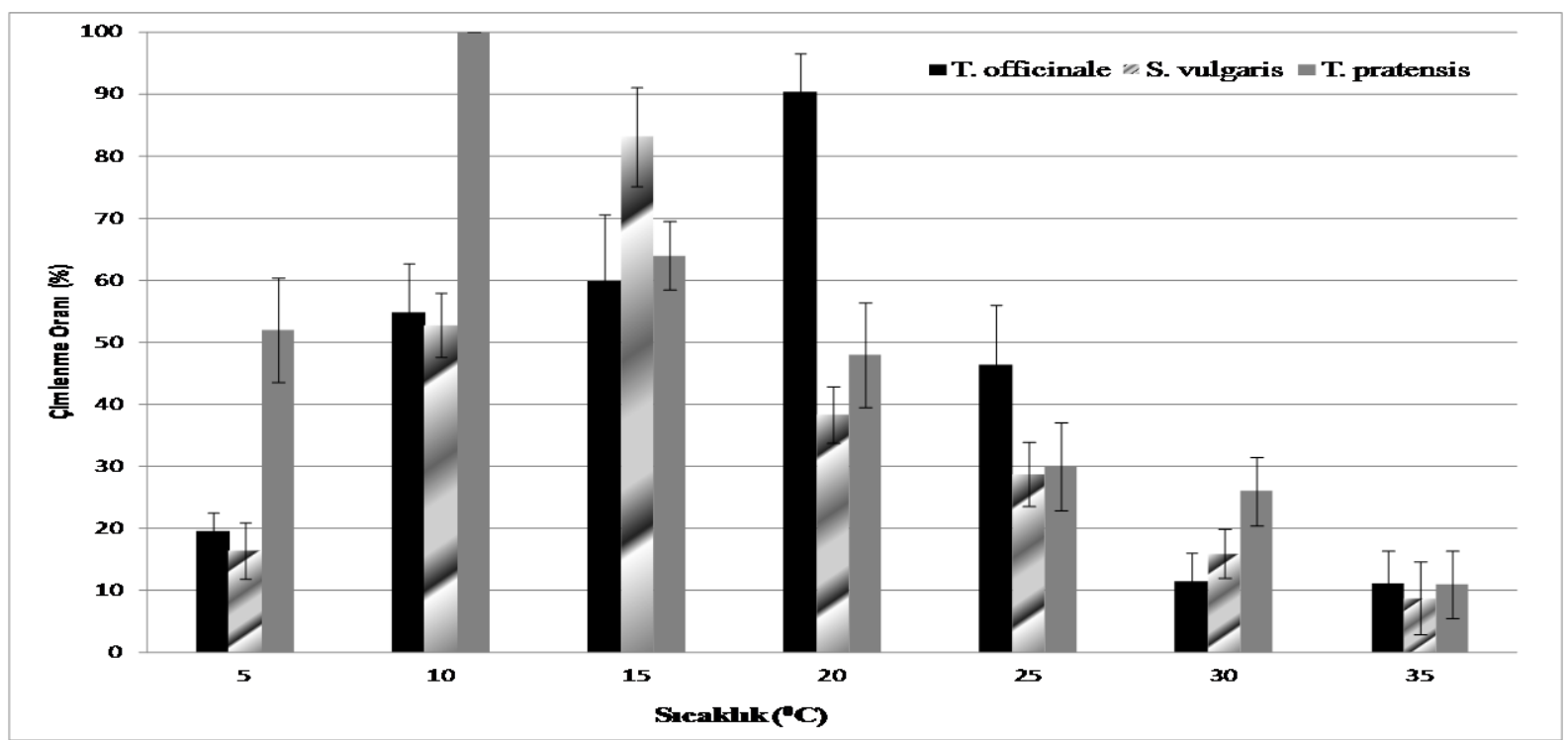

Şekil 1. Kullanılan üç yabancı otun farklı sıcaklıklardaki çimlenme oranları

Çalışmada uygulama yapılan tohumların çimlenme oranları arasında $\mathrm{P}<0.05$ önem seviyesinde istatistiki olarak farklar bulunmuş ve Çizelge 1 'de verilmiştir. Çalışmada uygun sicaklık dereceleri belirlendikten sonra bu sıcaklıklardaki 1şık istekleri de belirlenmiştir. $\mathrm{Bu}$ sicaklık derecelerinde yabancı otların 1 şık isteklerinde ise $S$. vulgaris (\% 83.6) ve T. officinale (\%
90.4) optimum 16 saat aydınlık/8 karanlık da en iyi çimlenme oranına sahip olduğu saptanırken, $T$. pratensis (\% 100) ise 24 saat karanlık ortamda en fazla çimlenme oranı belirlenmiştir. Bu yabancı otlardan $S$. vulgaris bu 1şı1k isteğinde \% 50'sinin çimlenmesi için 4 gün geçmesi gerekirken \% 90 çimlenmeye ulaşması için geçen süre 7.8 gün olarak belirlenmiştir. $T$. officinale $\% \quad 50$ 
çimlenme oranına 6.2 gün, \% 90'ının çimlenebilmesi için ise 10.6 günün geçmesi gerektiği saptanmıştır. Bu üç yabancı ot tohumu içerinde en hızlı çimlenme oranına sahip olanı T. pratensis olarak saptanmıştır. En uygun 1 şı is isteğinde $\% \quad 50$ çimlenme oranına ulaşabilmek için $T$. pratensis bitkisi 1.6 gün, \% 90 oranına ulaşabilmek için ise 2 güne ihtiyaç duymaktadır. $\mathrm{Bu}$ değerler bize bu yabancı otların uygun şartlar sağlandığında hızlı bir çimlenme oranına sahip olabileceğini göstermektedir (Çizelge 1). $T$. officinale'nin tohumlarının $5-35{ }^{0} \mathrm{C}$ ' de çimlendiğini (Mezynski ve Cole 1974, Washitani, 1984), buna karşılık yüksek sıcaklıkta çimlenme oranının düştüğünü belirtmişlerdir (Martincova ve Honek 1997). Collins (2000) \% 85-94 tohumların çimlendiğini bulmuş ve $15^{\circ} \mathrm{C} / 5^{0} \mathrm{C} 9$ saat aydınlı, $25^{\circ} \mathrm{C} / 10{ }^{0} \mathrm{C} 14$ saat aydınlık, $35{ }^{0} \mathrm{C} / 20{ }^{0} \mathrm{C} \quad 15$ saat aydinlı, $25^{\circ} \mathrm{C} / 10^{\circ} \mathrm{C} \quad 24$ saat karanlık çimlenmeye tabi tutmuş. Diğer taraftan tamamen karanlıkta diğer sicaklık rejimlerinde çimlenme oranı düşmüştür. $\mathrm{Bu}$ sıcaklık rejimleri $35^{\circ} \mathrm{C}$ $120^{\circ} \mathrm{C}^{\prime}$ de $\% 75$ çimlenme, $15^{\circ} \mathrm{C} / 5^{\circ} \mathrm{C}^{\prime}$ de $\% 45$ çimlenme olmuştur. Mezynski ve Cole (1974) taze tohumlardaki maksimum çimlenme oranının değişik sıcaklıklarda $20^{\circ} \mathrm{C} 16$ saat ve $10^{\circ} \mathrm{C}$ 'de 8 saat tutulduğunda maksimum çimlenme oranı elde ettiklerini, buna karşılık 30 gün bekletilmiş tohumlarda en iyi çimlenmenin $20^{\circ} \mathrm{C} / 15^{\circ} \mathrm{C}$ elde ettiklerini bildirmişlerdir. Maguire ve Overland (1959)'da karanlıkta $15^{\circ} \mathrm{C}$ 'de sabit sicaklıkta sadece \% 4 çimlenme oranı elde edilirken değișen 1 şık ve karanlık ortamlarında $15^{\circ} \mathrm{C}$ (aynı sicaklık) \% 16 oranında çimlenme sağladıklarını bildirmişlerdir. Thompson (1989) ve Williams (1983) yaptıkları çalışmada benzer sonuçları bulmuşlardır. Tohum çimlenmesinin karanlık ortamda aydınlık ortamdan daha fazla uniform, daha hızlı ve daha fazla olduğunu tespit etmişlerdir (Issestein, 1992, Letchamo ve Gosselin 1996). Yapilan bu çalışmalar hem 1 şık hemde sıcaklık yönünden $T$. officinale ile ilgili yapılan çalışmalarla benzerdir.

Bekleme süreleri bakımından 6 ay bekleme süresinde $S$. vulgaris $\%$ 83.6, T. officinale'de \% 90.4 çimlenme oranına sahip olduğu, T. pratensis'de ise 2, 4 ve 6 ay bekletildiğinde $\% 100$ oranında bir çimlenme gerçekleştiği tespit edilmiştir. 6 aylık bekletme süresinde \% 50 çimlenme oranına ulaşabilmek için $\mathrm{S}$. vulgaris'de 4 gün beklemek gerekirken, $T$. officinale'de 6.2 gün ve $T$. pratensis'te 1 gün beklemek gerektiği sonucuna varılmıştır. \% 90 çimlenme ise S. vulgaris'de 7.8 gün iken, T. officinale'de 10,6 gün olarak bulunmuştur. En yüksek çimlenme oranına sahip olan $T$. pratensis'de ise 6 ay bekletmede 2.0 gün olarak saptanmıştır (Çizelge 1). İpek ve ark., (2008), Çemen ve kimyon tohumlarının çimlenmesi üzerine yaptıkları çalışmada çemen tohumunun 24 aya kadar bekletilmesinde çimlenme oranında bir değişme olmadığını ancak kimyon tohumlarında ise 9 aya kadar bekletilen tohumlarda çimlenme oranının en yüksek olduğu ancak 12 aydan sonra çimlenme oranının \% 50 oranında azaldığını bildirmişlerdir. Yaptığımız çalışmada üç yabancı ottada bu sürenin 6 ay olduğu belirlenirken İpek ve ark. (2008) ile bir noktaya kadar benzerlik göstermektedir. Ayrıca T. officinale'nin tohum çimlenme kapasitesinin \% 80-90 arasındadır (Falkowski ve ark.,1989) ve Martincova ve Honek (1997) tohumlar toplandıktan 28 gün sonra nemlendirilmiş petri kaplarında çimlenme oranının \% 94'e kadar çıktığını tespit etmişlerdir. Al-Hially (1996)'de T. officinale 'inde çimlenme oranının 90 gün bekledikten sonra daha artığını tespit etmiştir. Yine bu durum $T$. officinale tohumlarının bekletilmesi bu çalışma ile uyumludur.

Denemedeki diğer konulardan olan $\mathrm{pH}$ ve tuz çalışmaları, S. vulgaris için $15^{\circ} \mathrm{C}, 16$ saat aydınlık/8 saat karanlık ortamda ve 6 ay, T. officinale için $20^{\circ} \mathrm{C}, 16$ saat aydınlık/8 saat karanlık ortamda, 6 ay ve $T$. pratensis için ise $10^{\circ} \mathrm{C}, 24$ saat karanlık ortamda ve 6 ay bekletilen tohumlarda denemeler yapılmıştır.

$\mathrm{pH}$ istekleri bakımından $S$. vulgaris en uygun $\mathrm{pH}$ 7 'de \% 83.6 oranı ile en yüksek çimlenme oranına sahip olduğu saptanmıştır. Bunu $\mathrm{pH} 6$ ve 5 takip etmiştir. $\mathrm{Bu}$ pH oranları Taraxacum officinale'de 7 ve 6 olarak (\% 90.4) bulunmuştur. Tragopon pratensis'de ise $\mathrm{pH} 7$ 'de 100 oranında çimlenme elde edilmiştir. S. vulgaris'in pH 7'de \% 50'sinin çimlenmesi için 4 gün geçmesi gerekirken \% 90 çimlenmeye ulaşması için 7.8 gün geçmesi gerektiği saptanmıştır. Aslan dişinde ise 7 ve 6 $\mathrm{pH}$ 'da \% 50'sinin çimlenmesi için sırasıyla 6.2 ve 5.8 gün, \% 90 çimlenme içinde sırasıyla 10.6 ve 10.2 güne ihtiyacı vardır. T. pratensis'de ise $\mathrm{pH} \quad 7$ 'de $\% 50$ çimlenme için 1.6 gün, \% 90 çimlenme için 1.0 gün olarak saptanmıştır (Çizelge 1). Çalışılan bu üç tıbbi olarak kullanılan yabancı ota benzer şekilde Okay ve Günoz (2009), yaptıkları çalışmada Centaurea tchihatcheffii Fisch. et Mey.'da pH seviyesinin artması durumunda tohum çimlenmesinin olumsuz yönde etkilendiğini, en düşük çimlenmenin $\mathrm{pH} \quad 8.5$ 'de olduğunu bildirmişlerdir. En iyi çimlenmensin ise 6.5$7.5 \mathrm{pH}$ 'da saptadıklarının bildirmişlerdir. Yapılan çalışmada elde edilen sonuçlar Okay ve Günoz (2009) ile benzerlik göstermektedir. Ayrıca T. officinale'nin 4.8-7.6 pH arasındaki ortamlarda iyi geliştiğini belirtilmekte (Von Hofsten, 1954) bu da T. officinale ile yapılan çalışmayla uyum göstermektedir.

Üç yabancı ot tohumu da tuz istekleri bakımından \% 0 'da en yüksek çimlenme oranı göstermişlerdir. Yine $T$. pratensis \% 100 oranında çimlenme gösterirken bunu \% 90.4 ile $T$. officinale ve \% 83.6 ile $S$. vulgaris izlemiştir. Bu 3 tohumda \%50 çimlenme oranı $S$. vulgaris'de 4.0 gün, T, officinale'de 6.2 gün ve $T$. pratensis'de 1.6 gündür. \% 90 çimlenme ise $S$. vulgaris'de 7.8 gün, $T$. officinale'de 10.6 gün ve $T$. pratensis'de 1.0 gün olarak tespit edilmiştir (Çizelge 1). Tuz bitkiler için abiyotik şartlardan birini sağlaması ve önemli fizyolojik gelişmelere karşı negatif etki göstermesinden (Greenway ve Muns 1980, Lambers ve ark., 1998) dolayı bu çalışmada da aynı etki saptanmıştır. 
Çizelge 1. Yabanc1 otlara uygulanan uygulamaların etkisi ve $\mathrm{G}_{50}$ ile $\mathrm{G}_{10-90}$ değerleri

\begin{tabular}{|c|c|c|c|c|c|c|c|c|c|c|c|c|}
\hline \multirow{3}{*}{\multicolumn{2}{|c|}{ Uygulamalar }} & \multicolumn{4}{|c|}{ Senecio vulgaris L. } & \multicolumn{4}{|c|}{ Taraxacum officinale L. } & \multicolumn{3}{|c|}{ Tragopogon pratensis L. } \\
\hline & & \multicolumn{2}{|c|}{ G-max } & \multirow{2}{*}{$\begin{array}{l}\mathrm{G}_{50} \\
\text { (gün) }\end{array}$} & \multirow{2}{*}{$\begin{array}{l}\mathrm{G}_{10-90} \\
\text { (gün) }\end{array}$} & \multicolumn{2}{|c|}{ Gmax } & \multirow{2}{*}{$\begin{array}{l}\mathrm{G}_{50} \\
\text { (gün) }\end{array}$} & \multirow{2}{*}{$\begin{array}{l}\mathrm{G}_{10-90} \\
\text { (gün) }\end{array}$} & Gmax & \multirow{2}{*}{$\begin{array}{l}\mathrm{G}_{50} \\
\text { (gün) }\end{array}$} & \multirow{2}{*}{$\frac{\mathrm{G}_{10-90}}{\text { (gün) }}$} \\
\hline & & $\%$ & [Gmax] & & & $\%$ & [Gmax] & & & $\% \quad[$ Gmax $]$ & & \\
\hline \multirow{4}{*}{ pH } & 4 & $19.2 \mathrm{c}$ & {$[25.96]$} & 4.6 & 8.2 & $37.2 \mathrm{c}$ & [37.58] & 5.4 & 8.6 & $84.0 \mathrm{~cd} \quad[66.65]$ & 4.6 & 5.6 \\
\hline & 6 & $68.0 \mathrm{~b}$ & [55.61] & 5.4 & 8.6 & $90.4 a$ & [74.92] & 5.8 & 10.2 & $96.8 \mathrm{ab} \quad[82.10]$ & 2.0 & 4.2 \\
\hline & 7 & $83.6 \mathrm{a}$ & [66.60] & 4.0 & 7.8 & $90.4 \mathrm{a}$ & {$[73.92]$} & 6.2 & 10.6 & $100.0 \mathrm{a} \quad[90.00]$ & 1.6 & 2.0 \\
\hline & 8 & $17.6 \mathrm{c}$ & [24.76] & 4.4 & 6.0 & $62.4 \mathrm{~b}$ & {$[52.20]$} & 7.6 & 11.0 & [77.07] & 2.6 & 4.0 \\
\hline & & \multicolumn{4}{|c|}{ LSD: 12.2} & \multicolumn{4}{|c|}{ LSD: 10.6} & \multicolumn{3}{|l|}{ LSD: 6.1} \\
\hline \multirow{4}{*}{$\begin{array}{c}\text { Işık/ } \\
\text { Karanlık }\end{array}$} & $24 \mathrm{~h}$ aydınlık & $31.2 \mathrm{~d}$ & [33.94] & 7.0 & 8.6 & $59.6 c$ & {$[50.61]$} & 4.8 & 6.0 & $67.2 \mathrm{c}$ [55.09] & 2.0 & 4.4 \\
\hline & 24 h karanlık & $17.6 \mathrm{c}$ & [24.67] & 7.6 & 8.4 & $56.8 \mathrm{c}$ & [48.99] & 10.8 & 11.2 & $100.0 \mathrm{a} \quad[90.00]$ & 1.6 & 2.0 \\
\hline & $16 \mathrm{~h}$ aydınlık/ $8 \mathrm{~h}$ karanlık & $83.6 \mathrm{a}$ & [66.60] & 4.0 & 7.8 & $90.4 a$ & [73.92] & 6.2 & 10.6 & {$[52.75]$} & 2.2 & 5.4 \\
\hline & $8 \mathrm{~h}$ aydınlık/ $16 \mathrm{~h}$ karanlık & $56.0 \mathrm{~b}$ & [48.48] & 4.8 & 8.4 & $70.8 b$ & [58.20] & 4.0 & 4.0 & [60.77] & 2.0 & 2.6 \\
\hline & & \multicolumn{4}{|c|}{ LSD: 11.8} & \multicolumn{4}{|c|}{ LSD: 6.7} & \multicolumn{3}{|l|}{ LSD: 8.2} \\
\hline \multirow{5}{*}{$\begin{array}{c}\text { Bekleme } \\
\text { Süresi }\end{array}$} & Taze & $13.0 \mathrm{c}$ & [22.90] & 10.8 & 11.6 & $11.6 \mathrm{e}$ & [19.87] & 3.4 & 4.8 & {$[55.08]$} & 3.6 & 5.8 \\
\hline & 1 ay & $15.2 \mathrm{c}$ & [22.90] & 9.2 & 8.2 & $17.2 \mathrm{e}$ & [24.44] & 7.0 & 8.8 & [66.98] & 4.4 & 5.2 \\
\hline & 2 ay & $18.8 \mathrm{c}$ & [25.65] & 7.2 & 8.0 & $35.6 \mathrm{~d}$ & {$[36.60]$} & 7.6 & 11.2 & [90.00] & 2.0 & 2.4 \\
\hline & 4 ay & $34.0 \mathrm{~b}$ & [35.65] & 4.4 & 8.2 & $72.4 b$ & [58.41] & 2.6 & 7.0 & {$[90.00]$} & 1.6 & 2.2 \\
\hline & 6 ay & $83.6 \mathrm{a}$ & [66.60] & 4.0 & 7.8 & $90.4 \mathrm{a}$ & [73.92] & 6.2 & 10.6 & [90.00] & 1.6 & 2.0 \\
\hline & & \multicolumn{4}{|c|}{ LSD: 13.6} & \multicolumn{4}{|c|}{ LSD: 7.1} & \multicolumn{3}{|l|}{$L S D: 5.8$} \\
\hline \multirow{6}{*}{$\begin{array}{l}\text { Tuz } \\
(\%)\end{array}$} & 0 & $83.6 \mathrm{a}$ & [66.60] & 4.0 & 7.8 & $90.4 a$ & [73.92] & 6.2 & 10.6 & [90.00] & 1.6 & 2.0 \\
\hline & 0.5 & $69.2 b$ & {$[56.49]$} & 5.0 & 8.6 & $50.8 b$ & [45.46] & 8.6 & 9.4 & [69.11] & 2.0 & 3.4 \\
\hline & 1 & $59.2 \mathrm{c}$ & [50.43] & 5.2 & 9.4 & $37.2 \mathrm{c}$ & {$[37.53]$} & 8.4 & 10.8 & [68.45] & 2.2 & 3.0 \\
\hline & 2 & $50.8 \mathrm{c}$ & [45.46] & 6.2 & 10.4 & $24.4 d$ & [29.58] & 7.4 & 11.8 & [61.49] & 2.6 & 3.8 \\
\hline & 4 & $14.4 \mathrm{~d}$ & [22.13] & 12.0 & 13.4 & $11.6 \mathrm{e}$ & {$[19.84]$} & 5.6 & 7.4 & [54.11] & 3.2 & 5.2 \\
\hline & & \multicolumn{4}{|c|}{$L S D: 8.9$} & \multicolumn{4}{|c|}{$L S D: 7.5$} & \multicolumn{3}{|l|}{$L S D: 5.1$} \\
\hline
\end{tabular}

*Tırnaklar içerisinde ki değerler Archine dönüştürülmüş verilerdir. 


\section{SONUÇ}

Yapılan denemeler sonucu 1şı̆̆ında bu üç tıbbi olarak kullanılan yabancı otun yetiştiriciliği ve üretimi yapılmak istediğinde sıcaklığın düşük olduğu erken ilkbaharda en erken $T$. pratensis'in, daha sonraki dönemlerde ise $S$. vulgaris ve $T$. officinalis'in ekiminin yapılabileceğini söylemek mümkündür. Ayrıca bu üç tohumun yaptığımız çalışmalardaki bekletme sürelerine göre taze olarak kullanılmayıp her üç tohumunda belirli bir süre bekletilmesi gerekmektedir (çalışmamızda bu süre 6 ay olarak saptanmıştır). Ayrıca bu tıbbi olarak kullanılan yabancı otlar için toprak asitliği yönünden nötr toprakları tercih ettiği sonucuna varabiliriz.

\section{KAYNAKLAR}

Ağaoğlu, Y.S., Çelik, H., Çelik, M., Fidan, Y., Gülşen, Y., Günay, A., Halloran, N., Köksal, A.İ., Yanmaz, R., 1997. Genel Bahçe Bitkileri. Ankara Üniversitesi Ziraat Fakültesi Eğitim, Araştırma ve Geliştirme Vakfı Yayınları No:4, 369 s.

Akınc1, I.E., Akınc1, S., 2010. Effect of Chromium Toxicity on Germination and Early Seedling Growth in melon (Cucumis melo L.) African Journal of Biotechnology, 9(29):4589-4594.

Al-Hially, T.A.K., 1991. Studies on the Biology and Control of Perennial Weeds with Special reference to dandelion (Taraxacum officinale Weber). Ph.D Thesis, University of Wales, Bangor, UK. 147 pp.

Almansori, M., Kinet, J.M., Luts, S., 2001. Effect of Salt and Osmotic Stresses on Germination in Durum Wheat (Triticum durum Desf.). Plant Soil, 231:245-256.

Baskın, J.M., Baskın, C.C., 1988. Role of Temperature in Regulating the Timing of Germination in Portulaca oleracea. Canadian Journal of Botany, 66: 563-567.

Başer, K.H.C., 1998. Tıbbi ve Aromatik Bitkilerin Endüstriyel Kullanımı. Anadolu Üniversitesi, Tıbbi ve Aromatik Bitki ve İlaç Araştırma Merkezi Bülteni (13-14): 19-44.

Baydar. H., 2013 Tibbi ve Aromatik Bitkiler Bilimi ve Teknolojisi. Süleyman Demirel Üniversitesi Yayınlar1, $300 \mathrm{~s}$.

Collins, L.L., 2000. The Effect of Date of Seed Maturation and Seed Size on Seed Germination and Seedling Emergence of the Dandelion, Taraxacum officinale Weber. MSc. Thesis, University of Western Ontario, London, 96 pp.

Clark, W.M., Lubs, H.A., 1915. Hydrojen Electrode Potentials of Phthalate, Phosphate and Borate Buffer Mixtures. Jour. Biol. Chem. XXV:479-510.

Çavuşoğlu, K., Kılıç, S., Kabar, K., 2007. Tuzlu (NaCl) Koşullar Altındaki Tohum Çimlenmesi, Fide Büyümesi ve Yaprak Anatomisi üzerine Triakontanol Ön Uygulamasının Etkileri. Süleyman Demirel Üniversitesi Fen Edebiyat Fakültesi Fen Dergisi, 2(2): 136-145.
Çöteli, E. , Karataş, F., 2015. Yemlik (Tragopogon reticulatus) Bitkisinin Yapraklarındaki Glutatyon ve Vitamin Miktarları ile Toplam Antioksidan Kapasitesinin Araştırılması. Güfbed/Gustij, 5(2):78-86.

Dash, M., Panda, S.K., 2001. Salt Stress Induced Changes in Growth and Enzyme Activities in Germinating Phaseolus Mungo Seeds. Bioligia Plantarum, 44(4): 587-589.

Davis, P.H., 1965-1985. Flora of Turkey and the East Aegean Islands, Edinburg University Press, Vol. 19, Edinburg

Davis, P.H., Mill. R. ve Tan, K., 1988. Flora of Turkey and the East Aegean Islands, (Supplement) Edinburg University Pres, Vol. 10, Edinburg.

Demir, I., Mavi, K., M., Okçu, G., 2003, Effect of Salt Stress on Germination and Seedling Growth in Serially Harvested Aubergine (Solanum melongena L.) Seeds during Development. Israel Journal of Plant Science, 51:125-131.

Falkowski, M., Kukulka, I., Kozlowski, S., 1989. Characterization of Biological Properties and Fodder Value of Dandelion, Taraxacum officinale Web. Pages 775-776 in Proceedings of the XVI International Grassland Congress, Nice-France.

Ghorbani, R., Seel, W., Leifert, C., 1999. Effects of Environmental Factors on Germination and Emergence of Amaranthus retroflexus. Weed Science, 47: 505-510.

Greenway, H., Muns R., 1980. Mechanisms of Salt Tolerance in Nonhalophytes. Annu. Rev. Plant Physiol., 31:149-190.

Güner, A., Özhatay, N., Ekim, T. ve Başer, KHC., 2000. Flora of Turkey and the East Aegean Islands (supp. 2), Vol.11, Edinburgh: Edinburgh University Press.

Güneş, A., Alpaslan, M., İnal, A., 2000. Bitki Besleme ve Gübreleme. Ankara Üniversitesi Ziraat Fakültesi Yayın No: 1514, Ankara, 576 s.

Gulzar, S., Khan, M.A., 2002. Alleviation of SalinityInduced Dormancy in Perennial Grasses. Bioligia Plantarum, 45(4):617-619.

Hayta, E., Arabacı, O., 2011. Kekik Olarak Adlandırılan Bazı Bitki Cinslerinin Tohumlarında Farklı Çimlendirme Yöntemlerinin Belirlenmesi. Adnan Menderes Üniversitesi Ziraat Fakültesi Dergisi, 8(1):91-101.

Heydecker, W., Coolbear, P., 1977. Seed Treatments for Improved Performance Survey Pragnosis. Seed Sci. And Tech., 5:353-425.

İpek, A., Kaya, M.D., Gürbüz, B., 2008. Çemen (Trigonella foenum-graecum L.) ve Kimyon (Cuminum cyminum L.) Tohumlarının Çimlenmesi Üzerine Tohum Yaşı ve GA3 Uygulamalarının Etkileri. Ankara Üniversitesi Ziraat Fakültesi Tarım Bilimleri Dergisi, 14(4):57-61. 
Isseltein, J., 1992. Studies on the Variability of Germination of Taraxacum officinale Web. Z. Pflanzenk. Pflanzen, 13:119-125.

Jalink, H., Van Der Schoor, I.R., 2000. Seed Calcular 2.2 User's Guide. Report 10. Planth Research International, Wageningen.

Kabar, K., Baltepe, S., 1987. Alleviation of Salinity Stress on Germination of Barley Seeds by Plant Growth Regulators. Turkish Journal of Biology, 11(3):10-117

Kalafatçı, Ö. A., Kalafatçı, İ., 2010. Bitkiler ve Sağlık 'Fitoterapi'. Sidas Yayınları, $486 \mathrm{~s}$.

Karakurt, H., Aslantaş, R., Eşitken, A., 2010. Tohum Çimlenmesi ve Bitki Büyümesi Üzerinde Etkili Olan Çevresel Faktörler ve Bazı ön Uygulamalar. Uludağ Üniversitesi Ziraat Fakültesi Dergisi, 24(2):115-128.

Lambers, H., Chapin, F. S., III, Pons T. L., 1998. Plant Physiological Ecology. New York: Springer pp. 277-280.

Letchamo, W., Gosselin, A., 1996. Light, Temperature and Duration of Storage Govern the Gerination and Emergence of Taraxacum officinale Seed. J. Hortic. Sci., 71:373-377.

Li, H., Kolluri, S.K., Gu, J., Dawson, M.I., Cao, X., Hobbs, P.D., Lin, B., Chen, G., Lu, J., Lin, F., 2000. Cytochrome C Release and Apoptosis Induced by Mitochondrial Targeting of Nuclear Orphan Receptor TR3. Science, 289:1159-1164

Maguire, J.D., Overland, A., 1959. Laboratory Germination of Seeds of Weedy and Native Plants. Washington Agric. Exp. Sta. Circ., 349.15 pp.

Mansour, M.M.F., 1994, Changes in Growth, Osmotic Potential and Cell Permeability of Wheat Cultivars under Salt Stress. Biological Plant, 36: 429-434.

Martinkova, Z., Honek, A., 1997. Germination and Seed Viability in a Dandelion, Taraxacum officinale Agg. Ochr. Rostl., 33:125-133.
Mezynski, P.R., Cole, D.F., 1974. Germination of Dandelion Seed on a Thermogradient Plate. Weed Sci., 22:506-507.

Okay, Y., Günöz, A., 2009. Gölbaşı'na Endemik Centaurea tchihatcheffii Fisch. et Mey. Tohumlarının Cimlenmesi Üzerine Bazı Uygulamaların Etkisi. Ankara Üniversitesi Ziraat Fakültesi Tarım Bilimleri Dergisi, 15(2):119-126.

Otsamo, R., Adjers, G., Kuusipalo, J., Otsamo, A., Susilo N., Tuomela K., 1996. Effect of Nursey Practices on Seed Germination of Selected Dipterocarp Species. J. Trop. For. Sci., 9(1):23-24.

Özer, Z., Tursun, N., Önen, H., 2001. Yabancı Otlarla Sağlıklı Yaşam (Gıda ve Tedavi), 4 Renk Yayınları, 253s.

Schütz, W. 1997. Primary Dormancy and Annual Dormancy Cycles in Seeds of Six Temperate Wetland Sedges. Aquatic Botany, 59: 75-85.

Taiz, L., Zeiger, E, 1998. Plant Physiology. Sinauer Associates, Inc., Publishers, Sunderland, 792 p.

Thompson, K., 1989. A Comparative Study of Germination Responses to High Irradience Light. Ann. Bot., 63:159-162.

Von Hofsten, C.G., 1954. Studies on the Genus Taraxacum with Special Reference to the Group Vulgaria D.T. in Scandinavia. LTs Förlag, Stockholm, Sweden. 431 pp. [in Swedish, English abstract.]

Yentur, S. 1995. Bitki Anatomisi. İstanbul Üniversitesi Yayınları, 3808.

Washitani, I., 1984. Germination Responses of a Seed Population of Taraxacum officinale Weber to Constant Temperatures Including the SupraOptimal Range. Plant Cell Environ., 7:655-659.

Williams, E.D. 1983. Effect of Temperature, Light, Nitrate and Pre-chilling on Seed Germination of Grassland Plants. Ann. Appl. Biol., 103:161-172. 